\title{
AN OBJECT-BASED APPROACH FOR MONITORING THE EVOLUTION OF LANDSLIDE-DAMMED LAKES AND DETECTING TRIGGERING LANDSLIDES IN TAIWAN
}

\author{
Z. Dabiri ${ }^{1,}{ }^{*}$, D. Hölbling ${ }^{1}$, L. Abad ${ }^{1}$, G. Prasicek ${ }^{2,3}$, A.-L. Argentin ${ }^{2}$, T.-T. Tsai ${ }^{4}$ \\ ${ }^{1}$ Department of Geoinformatics - Z_GIS, University of Salzburg, 5020 Salzburg, Austria - (zahra.dabiri, daniel.hoelbling, \\ lorenacristina.abadcrespo)@sbg.ac.at \\ 2 Department of Geography and Geology, University of Salzburg, 5020 Salzburg, Austria - (guenther.prasicek, anne- \\ lauremarine.argentin)@sbg.ac.at \\ ${ }^{3}$ Center for Interdisciplinary Mountain Research, University of Lausanne, 1967 Bramois, Switzerland - gunther.prasicek@unil.ch \\ ${ }^{4}$ Disaster Prevention Education Center, National Cheng Kung University, Tainan City 701, Taiwan (R.O.C.) - \\ victor@dprc.ncku.edu.tw
}

KEY WORDS: Landslides, Landslide-Dammed Lakes, Remote Sensing, Object-Based Image Analysis (OBIA), Taiwan

\begin{abstract}
:
In August 2009, Typhoon Morakot caused a record-breaking rainfall in Taiwan. The heavy rainfall triggered thousands of landslides, in particular in the central-southern part of the island. Large landslides can block rivers and can lead to the formation of landslidedammed lakes. Cascading hazards like floods and debris flows after landslide dam breaches pose a high risk for people and infrastructure downstream. Thus, better knowledge about landslides that significantly impact the channel system and about the resulting landslide-dammed lakes are key elements for assessing the direct and indirect hazards caused by the moving mass. The main objectives of this study are 1) to develop an object-based image analysis (OBIA) approach for semi-automated detection of landslides that caused the formation of landslide-dammed lakes and 2) to monitor the evolution of landslide-dammed lakes based on Landsat imagery. For landslide and lake mapping, primarily spectral indices and contextual information were used. By integrating morphological and hydrological parameters derived from a digital elevation model (DEM) into the OBIA framework, we automatically identified landslide-dammed lakes, and the landslides that likely caused the formation of those lakes, due to the input of large amounts of debris into the channel system. The proposed approach can be adapted to other remote sensing platforms and can be used to monitor the evolution of landslide-dammed lakes and triggering landslides at regional scale after typhoon and heavy rainstorm events within an efficient time range after suitable remote sensing data has been provided.
\end{abstract}

\section{INTRODUCTION}

\subsection{Background}

Landslides play an important role in the evolution of landscapes (Guzzetti et al., 2012). They are a significant and frequent hazard in many areas in the world, including Taiwan. One particular event, Typhoon Morakot, caused a record-breaking rainfall, on August 9, 2009, which triggered thousands of landslides on the island (Tsou et al., 2011). Among them, the Xiaolin landslide, a large deep-seated landslide in southern-central Taiwan, which also dammed the river leading to the formation of a landslidedammed lake (Wu et al., 2014).

Earth Observation (EO) data provides a unique possibility to detect and monitor landslides and landslide-dammed lakes from space (Cigna, 2018; Delaney and Evans, 2015). However, there is a need for methods and algorithms to efficiently extract a maximum of information from the enormous amount of available EO imagery.

The main objectives of this study are: 1) to semi-automatically detect landslides that caused landslide-dammed lakes, using object-based image analysis (OBIA), and 2) to monitor the evolution of landslide-dammed lakes using EO imagery.

\subsection{Landslide-Dammed Lakes}

Landslide-dammed lakes are a type of watercourse obstruction in steep mountain environments, caused by a landslide event (Wang et al., 2019). Depending on the dam resistance, landslidedammed lakes might drain rapidly and trigger catastrophic debris flows and floods, or might be stable for many years (Liu et al., 2015). Landslides are mostly induced by heavy rainfall, earthquakes, and ice-snowmelt (Costa and Schuster, 1987).

Taiwan is particularly prone to landslides given its frequent rainfall and earthquake events (Hsu and Hsu, 2009; Wu et al., 2014). As a consequence, several studies of landslide-dammed lakes have been conducted in different regions on the island like Tsaoling (Hsu and Hsu, 2009) and Chiufengershan (Shou and Wang, 2003). Chen et al. (2014) collected data on landslideinduced dams in Taiwan and identified 35 landslide dams caused by rainfall, 23 landslide dams caused by earthquakes and six cases where the failure mechanism could not be classified.

Thus, better knowledge of the distribution and evolution of landslide-dammed lakes is crucial to understand the associated processes which cause them (Bury et al., 2013), as well as for emergency response (Bolch et al., 2008; Emmer et al., 2016).

\subsection{Object-based Image Analysis}

EO data has great potential for mapping, monitoring and analysis of landslides (cf. Casagli et al., 2016; Scaioni et al., 2014), and landslide-dammed lakes (Dong et al., 2014; Huggel et al., 2002; Tofani et al., 2013). Object-based image analysis (OBIA) has emerged as a new paradigm to analyse EO imagery (Blaschke, 2010; Blaschke et al., 2014; Chen et al., 2018). OBIA is highly suitable for detecting and mapping landslides from EO data by combining spectral, topographic, and textural features during image segmentation and classification (Hölbling et al., 2017; Martha et al., 2010; Stumpf and Kerle, 2011). 
Such a semi-automated approach can complement and improve existing approaches, combined with a degree of manual interpretation (Hölbling et al., 2016). Several studies have applied OBIA for landslide mapping in Taiwan (e.g. Eisank et al., 2014; Hölbling et al., 2015; Lahousse et al., 2011; Rau et al., 2012), however, none investigated the relationship between landslides and the channel system.

\section{STUDY AREA AND DATA}

\subsection{Study Area}

The study area is located in the south-central part of Taiwan. The area of interest mainly covers the mountainous parts of the Kaohsiung county (i.e. the northern part of the county). We slightly expanded the administrative boundary of the county to include a north-eastern watershed (Figure 1). Landslides strongly affect this area, especially after Typhoon Morakot, and potentially block rivers and thus lead to the formation of landslide-dammed lakes.

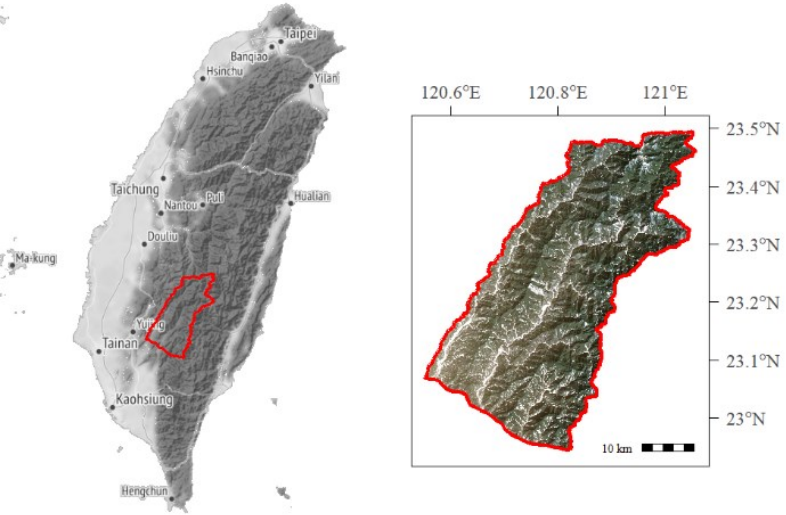

Figure 1. Study area in the south-central part of Taiwan.

\subsection{Data}

We used three Landsat 5 images acquired in the years after Typhoon Morakot and the ALOS PALSAR DEM (C) JAXA; Table 1).

\begin{tabular}{|l|c|c|}
\hline Sensor & $\begin{array}{c}\text { Acquisition } \\
\text { date }\end{array}$ & $\begin{array}{c}\text { Spatial } \\
\text { resolution }(\mathrm{m})\end{array}$ \\
\hline Landsat 5 & $2011 / 02 / 06$ & 30 \\
Landsat 5 & $2010 / 12 / 20$ & 30 \\
Landsat 5 & $2009 / 10 / 30$ & 30 \\
ALOS PALSAR DEM & $2007-2010$ & 12.5 \\
\hline
\end{tabular}

Table 1. Data used in this study.

\section{METHODS}

Figure 2 shows the workflow for object-based detection of landslide-dammed lakes and landslides. Part (a) illustrates the DEM processing to extract surface and hydrological parameters. Part (b) illustrates the workflow for processing and analysis of Landsat images.

\subsubsection{Data Pre-processing}

After mosaicking the digital elevation model (DEM), we derived 1) surface parameters, such as slope, aspect, and curvature, and 2) hydrological related parameters, such as flow-direction, flowaccumulation, stream order, and basin.

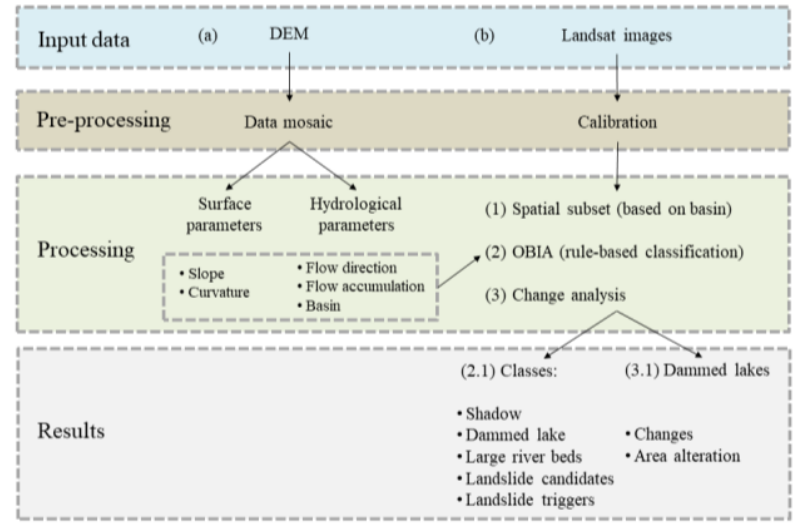

Figure 2. General methodological workflow.

We calibrated the Landsat images using the "apparent reflectance function" implemented in ArcGIS v.10.7. The calibration function uses data acquisition and sun elevation information, as well as radiance gain and bias, and sun irradiance for each band. The following spectral indices were derived from the preprocessed Landsat data and served as additional information layers during classification: 1) Normalized Difference Water Index (NDWI), 2) Normalized Difference Vegetation Index (NDVI), and 3) a brightness layer, defined as the mean of all spectral bands.

\subsubsection{Semi-automated Feature Extraction using OBIA}

For the OBIA rule-based feature extraction, we used the eCognition 9.4 (Trimble Geospatial) software. The three main steps for semi-automated detection of landslide-dammed lakes and triggering landslides included:

1. Creating spectral indices (NDWI, NDVI, brightness)

2. Multiresolution segmentation

3. Rule-based feature extraction

The multiresolution segmentation (Baatz and Schäpe, 2000) is a region growing algorithm, where the size and the shape of each segment is defined by the so-called scale parameter (SP). In this study, we set the SP to 10, and kept the default settings for the rest of the parameters. We defined five classes, with specific criteria applied for classification:

1. Shadow (extracted by defining thresholds using terrain slope and brightness)

2. Landslide-dammed lakes (extracted by defining a threshold using the NDWI)

3. Large river beds (extracted by defining thresholds using the NDWI and flow accumulation)

4. Landslide candidates (extracted by defining thresholds using the NDVI and the blue band).

5. Triggering landslides of dammed lakes (extracted using spatial relations to the class "landslide-dammed lakes")

The assumption for defining the class "triggering landslides" was that the nearest landslide downstream of the detected landslidedammed lake had the highest probably to cause it. Therefore, we generated spatial relations to the class landslide-dammed lakes, using the "distance map" algorithm implemented in the eCognition software. The layer contains the distance of pixels to objects of a selected class, using a flood-filtering algorithm. The triggering landslides were then extracted with a threshold. We applied the above-mentioned processes to all three Landsat images (Table 1). 


\section{RESULTS}

\subsection{Landslide-dammed lakes and triggering landslides}

We conducted a visual inspection for possible classification errors, whereby only small misclassifications (mostly in shadowed areas) were identified. Further, we compared the results to a reference dataset, created based on literature and visual interpretation, showing the location of dammed lakes and triggering landslides. Table 2 illustrates the number of landslidedammed lakes and their triggering landslides extracted for each year.

\begin{tabular}{|l|c|c|c|c|}
\hline $\begin{array}{l}\text { Landsat } \\
\text { image }\end{array}$ & \multicolumn{2}{|c|}{$\begin{array}{c}\text { No. of landslide- } \\
\text { dammed lakes }\end{array}$} & \multicolumn{2}{c|}{$\begin{array}{c}\text { No. of triggering } \\
\text { landslides }\end{array}$} \\
\hline \multirow{2}{*}{$2009 / 10 / 30$} & Reference & Detected & Reference & Detected \\
\cline { 2 - 5 } $2010 / 12 / 20$ & 3 & 2 & 3 & 3 \\
$2011 / 02 / 06$ & 4 & 4 & 5 & 4 \\
\hline
\end{tabular}

Table 2. Reference and detected landslide-dammed lakes and the landslides that most probably formed the dams.

As shown in Table 2, for the year 2009 we automatically extracted two landslide-dammed lakes out of three, for the year 2010 four landslide-dammed lakes out of five, and for the year 2011 three landslide-dammed lakes out of four. As for the triggering landslides, apart from one in the year 2010, all other landslides that led to the formation of a dammed lake were correctly detected.

\subsection{Analysis of changes for dammed lakes and triggering landslides}

Figures 3 illustrates the results of the semi-automated feature extraction for all three Landsat images, while Table 3 lists the landslide-dammed lakes appearance and/or disappearance for each year, along with their corresponding areas.

\begin{tabular}{|l|c|c|c|}
\hline ID & $\begin{array}{c}\text { Landslide- } \\
\text { dammed lake }\end{array}$ & Year & Area $\left(\mathrm{m}^{2}\right)$ \\
\hline \multirow{3}{*}{1} & & 2009 & 250,313 \\
& & 2010 & 237,187 \\
& & 2011 & 276,875 \\
\hline \multirow{3}{*}{3} & 2009 & 40,313 \\
& & 2010 & 20,468 \\
& & 2011 & Disappeared \\
\hline \multirow{3}{*}{4} & 2009 & 10,000 \\
& & 2010 & 18,437 \\
& & 2011 & 9,375 \\
\hline \multirow{3}{*}{$5 *$} & 2010 & no lake \\
& & 2011 & 187,656 \\
& & 217,968 \\
\hline
\end{tabular}

Table 3. Landslide-dammed lakes detected using semiautomated feature extraction. ${ }^{*}$ The triggering landslide for this landslide-dammed lake was not detected on 2010 (false negative in Table 2), however, it was detected on the 2011 image.
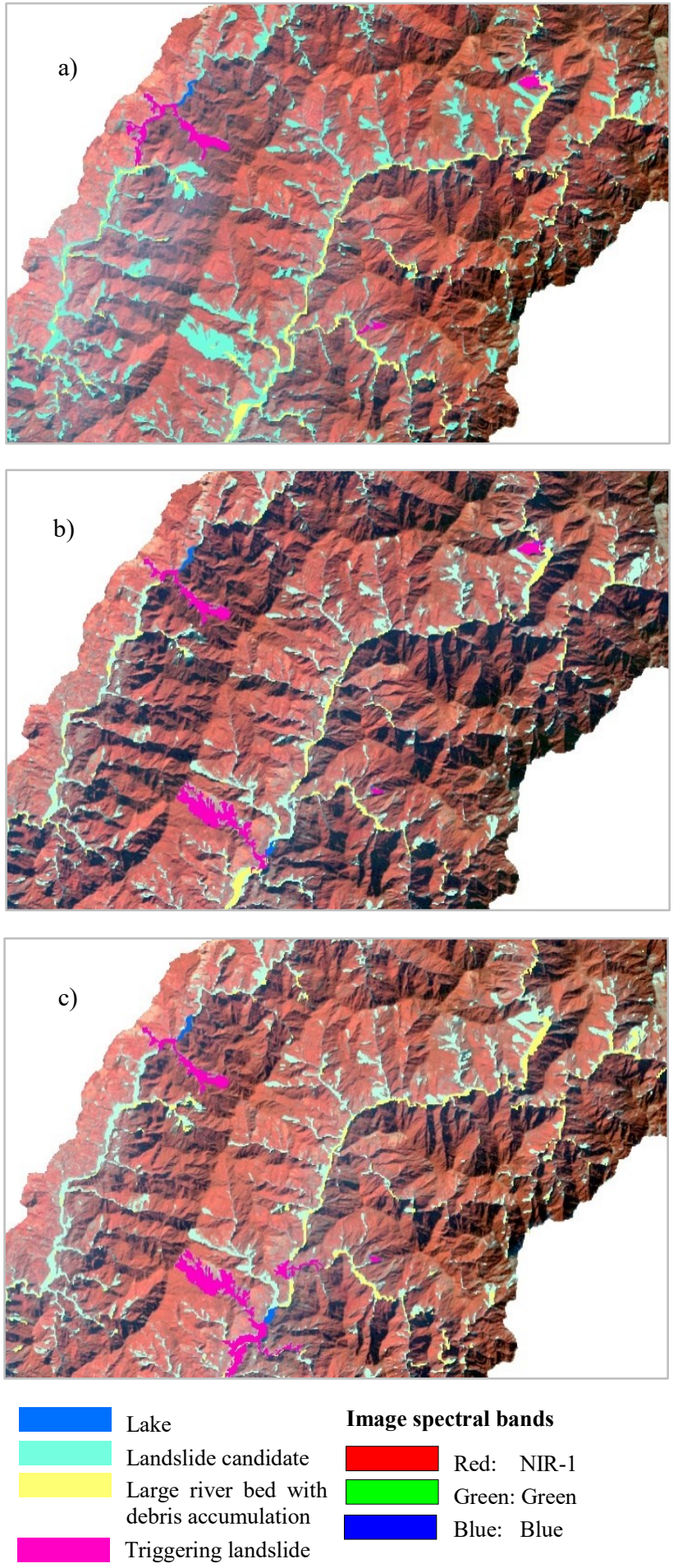

Figure 3. Illustration of the feature extraction results for the Landsat images from a) 2009/10/30, b) 2010/12/20, and c) 2011/02/06.

Three landslide-dammed lakes were identified in the Landsat image captured on 2009/10/30. A year later, on 2010/12/20 a new landslide-dammed lake appeared in the southern part of the shown subset, which was caused by the Butangbunasi landslide (cf. Hölbling et al., 2019). Another year later, on 2011/02/06, another small landslide-dammed lake appeared (also in the southern part of the shown subset), and the landslide-dammed lake in the north-east part disappeared. 
Figure 4 shows the trend in area changes for each landslidedammed lake. The area of the landslide-dammed lakes ID-1 and ID-4 increased. All the other landslide-dammed lakes showed a decline in their coverage area during the three investigated years.

-ID-1 - ID-2 $\bullet$ ID-3 $\bullet$ ID-4 $\bullet$ ID-5

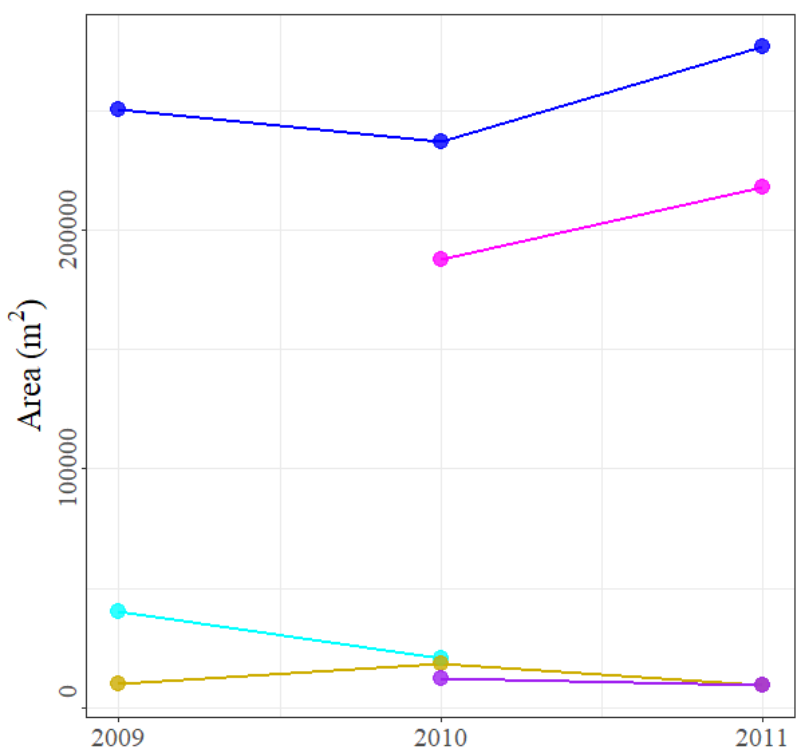

Figure 4. Changes in mapped area for each landslide-dammed lake during three successive years, 2009, 2010, and 2011. The IDs ( 1 to 5$)$ are the same as the IDs in Table 3.

\section{DISCUSSION}

The classification results for landslide-dammed lakes and triggering landslides were used for analysis of changes during the three successive years. The results of change analysis showed that the large landslide-dammed lake in the upper-right of the image subset (ID-1) increased in size; the landslide-dammed lake with ID-4 appeared first in 2010, and its area increased in the year 2011. The landslide-dammed lake with ID-2 disappeared on the image acquired on 2011. The landslide-dammed lake with ID-5 was first detected in the year 2010, and its area showed a decline in the year 2011 .

In general, we were able to extract the features of interest from all three Landsat images. However, because the images were taken at different times and under different illumination conditions, it was not possible to use unique thresholds for extracting the different classes from each Landsat image. Therefore, we set the classification thresholds for each image independently. The landslide-dammed lakes and their triggering landslides were successfully detected and extracted to a large extent. However, further work should be done to improve the exact delineation of triggering landslides to be able to draw further conclusions on the characteristics of landslides that impact the channel system. The transferability of this method needs to be closer investigated in future works.

\section{CONCLUSIONS}

In this research, we semi-automatically detected landslidedammed lakes and their triggering landslides using OBIA. Feature extraction relied on: a) surface parameters derived from a DEM, such as slope and curvature, b) hydrological parameters derived from a DEM, such as flow accumulation and basin, c) spectral indices, such as NDVI, NDWI and brightness(calculated separately for each year), and d) spectral information from Landsat 5 imagery for three successive years (2009/10/30,
2010/12/20, and 2011/02/06). Five classes were identified and extracted, namely: shadow, landslide-dammed lakes, landslide candidates, large river beds, and triggering landslides.

Better knowledge of the evolution of landslide-dammed lakes and their triggering factors are important key elements for hazard assessments (Ermini et al., 2006). The availability of EO data offer new opportunities for mapping and monitoring of such natural hazards (Cigna, 2018). However, to explore the value of these enormous amounts of data and to enhance time-series analyses, efficient methods are needed. In this research, we presented an approach for semi-automated mapping and monitoring of landslide-dammed lakes and detection of their triggering landslides. We showed that OBIA is a suitable method to map and monitor the evolution of landslide-dammed lakes and to identify their triggering landslides. The results highlight the suitability of our approach to monitor the evolution of landslidedammed lakes on freely available satellite imagery with global coverage.

\section{ACKNOWLEDGEMENTS}

This research has been supported by the Austrian Academy of Sciences (ÖAW) through the project RiCoLa (Detection and analysis of landslide-induced river course changes and lake formation), and by the Austrian Science Fund (FWF) through the Doctoral College GIScience (DK W 1237-N23). We would like to thank Barbara Friedl for supporting initial work.

\section{REFERENCES}

Baatz, M., Schäpe, A., 2000. Multiresolution Segmentation: an optimization approach for high quality multi-scale image segmentation. https://doi.org/10.1207/s15326888chc1304_3

Blaschke, T., 2010. Object based image analysis for remote sensing. ISPRS J. Photogramm. Remote Sens. 65, 2-16. https://doi.org/10.1016/J.ISPRSJPRS.2009.06.004

Blaschke, T., Hay, G.J., Kelly, M., Lang, S., Hofmann, P., Addink, E., Queiroz Feitosa, R., van der Meer, F., van der Werff, H., van Coillie, F., Tiede, D., 2014. Geographic Object-Based Image Analysis - Towards a new paradigm. ISPRS J. Photogramm. Remote Sens. 87, 180-191. https://doi.org/10.1016/J.ISPRSJPRS.2013.09.014

Bolch, T., Buchroithner, M.F., Peters, J., Baessler, M., Bajracharya, S., 2008. Identification of glacier motion and potentially dangerous glacial lakes in the Mt. Everest region/Nepal using spaceborne imagery, Nat. Hazards Earth Syst. Sci.

Bury, J., Mark, B.G., Carey, M., Young, K.R., McKenzie, J.M., Baraer, M., French, A., Polk, M.H., 2013. New Geographies of Water and Climate Change in Peru: Coupled Natural and Social Transformations in the Santa River Watershed. Ann. Assoc. Am. Geogr. 103, 363-374. https://doi.org/10.1080/00045608.2013.754665

Casagli, N., Cigna, F., Bianchini, S., Hölbling, D., Füreder, P., Righini, G., Del Conte, S., Friedl, B., Schneiderbauer, S., Iasio, C., Vlcko, J., Greif, V., Proske, H., Granica, K., Falco, S., Lozzi, S., Mora, O., Arnaud, A., Novali, F., Bianchi, M., 2016. Landslide mapping and monitoring by using radar and optical remote sensing: Examples from the EC-FP7 project SAFER. Remote Sens. Appl. Soc. Environ. 4, 92-108. https://doi.org/10.1016/J.RSASE.2016.07.001 
Chen, G., Weng, Q., Hay, G.J., He, Y., 2018. Geographic objectbased image analysis (GEOBIA): emerging trends and future opportunities. GIScience Remote Sens. 55, 159-182. https://doi.org/10.1080/15481603.2018.1426092

Chen, K.-T., Kuo, Y.-S., Shieh, C.-L., 2014. Rapid geometry analysis for earthquake-induced and rainfall-induced landslide dams in Taiwan. J. Mt. Sci. 11, 360-370. https://doi.org/10.1007/s11629-013-2664-y

Cigna, F., 2018. Observing geohazards from space. MDPI. https://doi.org/https://doi.org/10.3390/books978-3-03842-776-6 Costa, J.E., Schuster, R.L., 1987. The formation and failure of natural dams.

Delaney, K.B., Evans, S.G., 2015. The 2000 Yigong landslide (Tibetan Plateau), rockslide-dammed lake and outburst flood: Review, remote sensing analysis, and process modelling. Geomorphology 246, 377-393. https://doi.org/10.1016/J.GEOMORPH.2015.06.020

Dong, J.-J., Lai, P.-J., Chang, C.-P., Yang, S.-H., Yeh, K.-C., Liao, J.-J., Pan, Y.-W., 2014. Deriving landslide dam geometry from remote sensing images for the rapid assessment of critical parameters related to dam-breach hazards. Landslides 11, 93105. https://doi.org/10.1007/s10346-012-0375-z

Eisank, C., Hölbling, D., Friedl, B., Chen, Y.-C., Chang, K., 2014. Expert knowledge for object-based landslide mapping in Taiwan. South-Eastern Eur. J. Earth Obs. Geomatics 3, 347-350. Emmer, A., Klimeš, J., Mergili, M., Vilímek, V., Cochachin, A., 2016. 882 lakes of the Cordillera Blanca: An inventory, classification, evolution and assessment of susceptibility to outburst floods. CATENA 147, 269-279. https://doi.org/10.1016/J.CATENA.2016.07.032

Ermini, L., Casagli, N., Farina, P., 2006. Landslide dams: analysis of case histories and new perspectives from the application of remote sensing monitoring techniques to hazard and risk assessment. Ital. J. Eng. Geol. Environ. 45-52. https://doi.org/10.4408/IJEGE.2006-01.S-05

Guzzetti, F., Mondini, A.C., Cardinali, M., Fiorucci, F., Santangelo, M., Chang, K.-T., 2012. Landslide inventory maps: New tools for an old problem. Earth-Science Rev. 112, 42-66. https://doi.org/10.1016/J.EARSCIREV.2012.02.001

Hölbling, D., Betts, H., Spiekermann, R., Phillips, C., 2016. Identifying Spatio-Temporal Landslide Hotspots on North Island, New Zealand, by Analyzing Historical and Recent Aerial $\begin{array}{llll}\text { Photography. Geosciences } & 6,\end{array}$ https://doi.org/10.3390/geosciences6040048

Hölbling, D., Dabiri, Z., Tsai, T.-T., Prasicek, G., Tsui, C.Y., Schäffer, L., Argentin, A.-L., Abad, L., 2019. Mapping the Evolution of the Butangbunasi Landslide, Taiwan, using Landsat Time Series, in: 27th IUGG General Assembly. Montreal, Canada.

Hölbling, D., Eisank, C., Albrecht, F., Vecchiotti, F., Friedl, B., Weinke, E., Kociu, A., Hölbling, D., Eisank, C., Albrecht, F., Vecchiotti, F., Friedl, B., Weinke, E., Kociu, A., 2017. Comparing Manual and Semi-Automated Landslide Mapping Based on Optical Satellite Images from Different Sensors. Geosciences 7, 37. https://doi.org/10.3390/geosciences7020037

Hölbling, D., Friedl, B., Eisank, C., 2015. An object-based approach for semi-automated landslide change detection and attribution of changes to landslide classes in northern Taiwan. Earth Sci. Informatics 8, 327-335. https://doi.org/10.1007/s12145-015-0217-3

Hsu, Y.-S., Hsu, Y.-H., 2009. Impact of earthquake-induced dammed lakes on channel evolution and bed mobility: Case study of the Tsaoling landslide dammed lake. J. Hydrol. 374, 43-55. https://doi.org/10.1016/J.JHYDROL.2009.05.020

Huggel, Christian, Kääb, Andreas, Haeberli, Wilfried, Teysseire, P., Paul, Frank, Huggel, C, Kääb, A, Haeberli, W, Paul, F, 2002. Remote sensing based assessment of hazards from glacier lake outbursts: a case study in the Swiss Alps. Can. Geotech. J 39, 316-330. https://doi.org/10.1139/T01-099

Lahousse, T., Chang, K.T., Lin, Y.H., 2011. Natural Hazards and Earth System Sciences Landslide mapping with multi-scale object-based image analysis-a case study in the Baichi watershed, Taiwan. Hazards Earth Syst. Sci 11, 2715-2726. https://doi.org/10.5194/nhess-11-2715-2011

Liu, W., Lai, Z., Hu, K., Ge, Y., Cui, P., Zhang, X., Liu, F., 2015. Age and extent of a giant glacial-dammed lake at Yarlung Tsangpo gorge in the Tibetan Plateau. Geomorphology 246, 370 376. https://doi.org/10.1016/J.GEOMORPH.2015.06.034

Martha, T.R., Kerle, N., Jetten, V., van Westen, C.J., Kumar, K.V., 2010. Characterising spectral, spatial and morphometric properties of landslides for semi-automatic detection using object-oriented methods. Geomorphology 116, 24-36. https://doi.org/10.1016/J.GEOMORPH.2009.10.004

Rau, J.-Y., Jhan, J.-P., Lo, C.F., Lin, Y.S., 2012. Landslide mapping using imagery acquired by a fixed-wing UAV. Int Arch. Photogramm. Remote Sens. Spat. Inf. Sci. - ISPRS Arch. 38, 195-200. https://doi.org/10.5194/isprsarchives-XXXVIII-1C22-195-2011

Scaioni, M., Longoni, L., Melillo, V., Papini, M., Scaioni, M., Longoni, L., Melillo, V., Papini, M., 2014. Remote Sensing for Landslide Investigations: An Overview of Recent Achievements and Perspectives. Remote Sens. 6, 9600-9652. https://doi.org/10.3390/rs6109600

Shou, K.-J., Wang, C.-F., 2003. Analysis of the Chiufengershan landslide triggered by the 1999 Chi-Chi earthquake in Taiwan. Eng. Geol. 68, 237-250. https://doi.org/10.1016/S00137952(02)00230-2

Stumpf, A., Kerle, N., 2011. Object-oriented mapping of landslides using Random Forests. Remote Sens. Environ. 115, 2564-2577. https://doi.org/10.1016/J.RSE.2011.05.013

Tofani, V., Segoni, S., Agostini, A., Catani, F., Casagli, N., 2013. Climate of the Past Geoscientific Instrumentation Methods and Data Systems Solid Earth Technical Note: Use of remote sensing for landslide studies in Europe. Nat. Hazards Earth Syst. Sci 13, 299-309. https://doi.org/10.5194/nhess-13-299-2013

Tsou, C.-Y., Feng, Z.-Y., Chigira, M., 2011. Catastrophic landslide induced by Typhoon Morakot, Shiaolin, Taiwan. Geomorphology 127, 166-178. https://doi.org/10.1016/J.GEOMORPH.2010.12.013

Wang, H., Cui, P., Liu, D., Liu, W., Bazai, N.A., Wang, J., Zhang, G., Lei, Y., 2019. Evolution of a landslide-dammed lake 
on the southeastern Tibetan Plateau and its influence on river longitudinal profiles. Geomorphology 343, 15-32. https://doi.org/10.1016/J.GEOMORPH.2019.06.023

Wu, C.-H., Chen, S.-C., Feng, Z.-Y., 2014. Formation, failure, and consequences of the Xiaolin landslide dam, triggered by extreme rainfall from Typhoon Morakot, Taiwan. Landslides 11, 357-367. https://doi.org/10.1007/s10346-013-0394-4 